\title{
The study of the possibility of using domestic burnt magnesia in oil and petrol resistant rubber
}

\author{
(C) Nikolay F. Ushmarin, Evgeny N. Egorov and Nikolay I. Kol'tsov* ${ }^{+}$ \\ Department of Physical Chemistry and Macromolecular Compounds. Chuvash State University \\ of I.N. Ulyanov. Moskovsky Ave., 15. Cheboksary, 428015. Chuvash Republic. Russia. \\ Phone: +7 (8352) 45-24-68. E-mail: koltsovni@mail.ru
}

\begin{abstract}
*Supervising author; ${ }^{+}$Corresponding author Keywords: burnt magnesia, plasto-elastic and rheometric properties of the rubber mixture, physical and mechanical properties of oil-and-petrol resistant rubber.
\end{abstract}

\begin{abstract}
The article examines the oil-and-petrol resistant rubber mixture of type 7NO-68-1SK based on the combination of BNKS-18AMN grade butadiene-caoutchouc with polychloroprene caoutchouc of brand neoprene $\mathrm{W}$. The effect of replacing imported burnt magnesia brand Remag AC on domestic burnt magnesia technical grade B on the properties of the rubber compound and vulcanizate was studied. The rubber mixture was prepared on a laboratory roll mill LB 320 160/160, and then its standard samples were vulcanized at 150 ${ }^{\circ} \mathrm{C}$ for 30 minutes in a two-story electrically heated press of the VP 400-2E brand. To establish the plastoelastic properties of rubber mixture on the Mooney viscometer, MV 3000 was determined: the start time of the vulcanization, the time to reach the vulcanization mode, the initial maximum viscosity. To assess the kinetics of vulcanization of the rubber mixture on the rheometer MDR 3000 was determined: the start time of vulcanization, the time to reach the optimum vulcanization, the maximum torque. To assess the physicomechanical properties of rubber, the following were determined: conditional tensile strength; elongation at break; hardness; tear resistance and relative residual deformation under compression in accordance with the standards in force in the rubber industry. To assess the performance properties of rubber, changes in its mass were determined after aging in a mixture of isooctane + toluene, as well as standard liquid SJR-1. It has been shown that the introduction of burnt magnesia technical grade B into the rubber mixture does not lead to technological complications, magnesia is well distributed in the rubber matrix, and the magnesia agglomerates were not found on the rubber mixture sections. Replacement magnesium oxide $\mathrm{m}$. Remag AC on burnt magnesia technical grade $\mathrm{B}$ has an impact on the plastoelastic and rheometric properties of the rubber mixture. However of physicomechanical and operational properties vulcanizates of rubber mixture containing magnesium oxide $\mathrm{m}$. Remag AC and burnt magnesiatechnical grade B, have almost the same values.
\end{abstract}

\section{References}

[1] N.I. Koltsov, N.F. Ushmarin, A.E. Petrov, N.P. Petrov, N.N. Petrov, and S.M. Verhunov. Research of influence of technological additives on properties of rubbers on the basis of BNR new generation. Part 1. Vuhtazine RV/g-s. Butlerov Communications. 2010. Vol.19. No.2. P.79-86. ROI: jbc-02/10-19-2-79

[2] N.I. Koltsov, N.F. Ushmarin, L.G. Rogozhina, S.A. Issakova, A.V. Jarutkina, A.Y. Plehanova, and M.V. Kuzmin. Research of influence of technological additives on properties of rubbers on the basis of BNR new generation. Part 2. Elastid, oxsanoles and factice. Butlerov Communications. 2010. Vol.19. No.3. P.75-82. ROI: jbc-02/10-19-3-75

[3] N.I. Koltsov, N.F. Ushmarin, A.E. Petrov, N.P. Petrov, N.N. Petrov, and S.M. Verhunov. Research of influence of technological additives on properties of rubbers on the basis of BNR new generation. Part 3. Novantox 8 PFDA. Butlerov Communications. 2010. Vol.21. No.9. P.22-28. ROI: jbc-02/10-21-9-22

[4] N.I. Koltsov, N.F. Ushmarin, L.G. Rogozhina, S.A. Issakova, A.V. Jarutkina, A.Y. Plehanova, and M.V. Kuzmin. Research of influence of technological additives on properties of rubbers on the basis of BNR new generation. Part 4. Powder stabilizers on a basis novantox 8 PFDA. Butlerov Communications. 2010. Vol.22. No.10. P.42-50. ROI: jbc-02/10-22-10-42

[5] N.I. Koltsov, N.F. Ushmarin, N.P. Petrova, Yu.V. Vasileva, A.V. Yarutkina, N.N. Petrova, A.Y. Plekhanova, and M.V. Kuzmin. Research of influence of technological additives on properties of rubbers on the basis of BNR new generation. Part 5. Fire retardants on the basis of trichloroethylphosphate combinations. Butlerov Communications. 2012. Vol.29. No.2. P.62-68. ROI: jbc-02/12-29-2-62 
[6] S.I. Sandalov, M.S. Reznikov, N.F. Ushmarin, N.I. Kol'tsov. Development of thermo-aggressive rubber for packer elements. Bulletin of the Kazan Technol. University. 2014. Vol.17. No.9. P.129-132. (russian)

[7] I.S. Spiridonov, N.F. Ushmarin, E.N. Egorov, and N.I. Koltsov. Effect of functional ingredients on the technological properties of rubber mixtures for sealing elements. Butlerov Communications. 2017. Vol.51. No.7. P.132-136. DOI: 10.37952/ROI-jbc-01/17-51-7-132

[8] I.S. Spiridonov, N.F. Ushmarin, S.I. Sandalov, E.N. Egorov, and N.I. Koltsov. Effect of functional ingredients on the physico-mechanical and operational properties of rubber mixtures for sealing elements. Butlerov Communications. 2018. Vol.53. No.1. P.153-157. DOI: 10.37952/ROI-jbc-01/18-53-1-153

[9] N.F. Ushmarin, E.G. Efimovskiy, N.N. Petrova, S.I. Sandalov, N.I. Koltsov. Influence of powder schungite on the properties of oil-resistant rubber. Proceedings of higher educational institutions. Series "Chemistry and Chemical Technology". 2019. Vol.62. Iss.1. P.54-60. (russian)

[10] E.N. Egorov, N.F. Ushmarin, S.I. Sandalov, I.S. Spiridonov, and N.I. Koltsov. The influence of functional ingredients on the technological properties of water-oil-swelling rubber sealing elements. Butlerov Communications. 2019. Vol.57. No.1. P.95-100. DOI: 10.37952/ROI-jbc-01/19-57-1-95

[11] E.N. Egorov, N.F. Ushmarin, S.I. Sandalov, I.S. Spiridonov, and N.I. Koltsov. The influence of functional ingredients on the physico-mechanical and operational properties of rubbers for water-oilswelling sealing elements. Butlerov Communications. 2019. Vol.57. No.2. P.68-73. DOI: 10.37952/ROI-jbc-01/19-57-2-68

[12] E.G. Efimovskiy, N.F. Ushmarin, S.I. Sandalov, N.I. Kol'tsov, N.A. Kostikova, O.I. Korneeva, M.M. Antonova, and D.I. Klimov. Study of the possibility of using diafen FP, sulfenamide C and $N, N$ 'dithiodimorpholine of domestic production in rubber mixtures instead of imported analogues. Butlerov Communications. 2019. Vol.57. No.2. P.123-129. DOI: 10.37952/ROI-jbc-01/19-57-2-123 